\title{
家庭科住居領域における学習内容の構造に関する試行的研究 大学生の高校までの住居領域学習経験と学習志向の分析 \\ TRIAL STUDY ON THE STRUCTURE OF LEARNING CONTENTS OF HOUSING EDUCATION IN HOME ECONOMICS EDUCATION
}

Analysis of the learning experience until high school and intention of housing education

\author{
宮 㟝 陽子*, 多治見 左近**
}

\section{Yoko MIYAZAKI and Sakon TAJIMI}

\begin{abstract}
This paper examines college student's attitude to the learning contents of housing education. The results are as follows.
1. I analyzed the contents that students desire to learn about housing using factor analysis, and five factors were obtained. They are 'housing principle and culture', living environment', 'sociality of housing', 'planning and design' and 'maintenance and arrangement'.

2. The desired contents vary with the specialty of study, the leaning experience and gender.

3. As for the content of the social aspect of housing such as "History of the residence" and "Housing policy", the student had little experience of learning about them and felt not much interest in them.
\end{abstract}

\author{
Keywords : Housing education, Structuration, Learning content, University student, Learning \\ experience, Desire for learning \\ 住教育, 構造化, 学習内容, 大学生, 学習経験, 学習志向
}

1. はじめに

\section{(1) 研究の背景}

住教育は学校教育において、特に家庭科での住居領域学習を中心 に展開されてきた。関連研究で共通に指摘されている問題は、住居 領域の指導や学習の困難性である。

家庭科の場合、教師が住居領域の指導に苦手意識を抱いているこ と、適切な教材が不足していること、生徒の関心が低いことなど様々 な理由が、教師あるいは研究者の立場から指摘されている ${ }^{1)}$ 。その 背景には、住居領域の学習内容が専門的で広範囲であること、学ん だことを実生活に活かしにくいこと、学習者の居住状況の考察が住 生活の理解に有効であるにもかかわらずプライバシーに関わるため に考察しづらいことなどがある。

教員が住居領域に苦手意識を抱く背景要因として、それを学習す る機会や経験が少ないことが指摘される。しかしそれだけではなく、 学習内容自体の特性や領域性にも苦手意識を助長する原因があると も考えられる。学習内容のどんな側面が教員に苦手意識を持たせた り、教えにくさを感じさせたりすることになるのか。また学習者は どんな内容に関心や学習意欲を持ちや寸いのか。そうした視点で学 習内容の特性に着目することは、住教育を充実させていく上で重要 な視点であると考えた。
学習内容についてのこのような問題意識と、指導困難性の解決に 向けての研究活動や実践は各方面でなされている。例えば、「住教育 の推進方策と住教育ガイドラインの策定に関する検討調查」の報告 書では、学校現場における住教育の課題として、「住教育の具体的内 容や学習指導要領との関係が不明確で、授業で取り上げにくい」こ とを指摘している ${ }^{2)}$ 。また、住居領域内容の再検討を目的にして、 教師の指導要求と生徒の学習要求を把握したものとしては、湯川ら

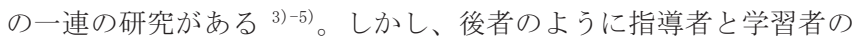
両者の立場から学習内容全体を捉えた研究は総じて多くはなく、教 師や生徒の住居領域への関心や要求の背景要因を探り、学習内容の 特性を明らかにしようとする研究もあまりみられない。

住居領域を構成する学習内容は、たくさんの要素でなりたちバラ エティに富んでいる。また異なる性質を持つ個々の要素が複雑に関 連しあっている。これらを的確に指導するためには、個々の学習内 容を充実させるとともにそれらによって構成される全体像を明らか にすること、つまり、住居領域の構造化が重要だと考える。その際 に指導者と学習者の双方の立場から、学習内容がどのように受け止 められているかは、教育現場の当事者の住居領域に対する意識構造 を反映するものと考えられ、住居領域の構造化にも寄与すると考え る。
$*$ 羽衣国際大学人間生活学部 講師・修士(教育学)

** 大阪市立大学大学院生活科学研究科 教授 $\cdot$ 工博
Instructor, Hagoromo University of International Studies, M. Edu.

Prof., Osaka City University, Dr. Eng. 


\section{(2) 研究の目的}

住教育の学習内容は先述のように、多様な要素が複雑な関係性を 持ち成り立っている。この、個々の学習内容 (具体的には学習項目) の意味や相互の関係性を把握し整理する取り組みを、本論では「学 習内容の構造化」と呼ぶ。住教育の学習内容を構造的に捉えること によって学習内容の特性を見出し、従来指摘されてきた「教えにく さ(指導困難性)」の要因を学習内容の側面からより詳しく明らかに できると考えている。

住居領域の学習内容の構造化には、指導者と学習者の双方からの 検討が必要であるが、本研究では家庭科の住居領域学習とその学習 者に焦点をあてて、(1)住居領域の学習内容についての学生（大学生） の関心事の特徴を明らかにすること、そして(2)その関心事に影響す る要素を明らかにすることを目的とする。例えば、学生が「学びた い」と思う、あるいは思わない学習内容に共通する意味を探ること や、そうした学習希望内容と学生の基本属性や学習経験等の条件が どんな関わりを持つかを探ることである。

「構造」とは一般に、要素とその組み合わせ、関係の総体を意味 するが、本研究で想定する「構造」も同様に、住居領域を構成する 多様な学習内容や概念が、論理的、学術分野的に、あるいは教育方 法や学習者意識のなかでいかなる関係性を持っているかということ である。その最終的な目標は、住居領域を構成する学習内容の、例 えば基礎的要素と発展的・応用的要素の関係性、学問体系としての 親近性、理念と実用の関係性などの側面から整理して、適切な教育 体系を構築することにある。当然ながら学術的側面からのみの構造 を机上の検討でまとめたとしても実効性に乏しいであろう。構造の 実際的な側面として、教育現場の教師や学習者の意識をも考慮し、 これと学術的側面からの構造と統合する必要があると考える。

本研究では学習者の意識の中で学習内容がどのように認識されて いるかを把握することを目的としている。それを十分に理解し、構 造化された住居領域学習に反映することにより学習者に受け入れや すくなることが期待される。

\section{2. 研究方法}

\section{(1) 調査対象と調査方法}

住居領域についてある程度の関心を持つと思われる家政・生活科 学系の大学生を対象にアンケート調查を実施した。表 1 のように、 対象校は大阪府下にある四年制大学 3 校 $(\mathrm{A}$ 大学・ B 大学・ C 大学 $)$ で、各大学に対応して専門分野が食物系・家政教育系・住居系に概 ね分かれている。高校卒業後間もない大学 1 回生が中心だが、一部 2 回生以上の学生も含まれている。

調查対象者の大学入学後の住居領域の教育は、A 大学食物系では 皆無、家政系では概論程度、B 大学では家庭科教員免許関連の専門 科目として受講しており 1 年次と 2 年次とで大差はない。C 大学で は概論程度を履修している。

調查は直接配票・直接回収で行い、調查時期は平成 22 年 7 月と 9 月で、有効回収票は 142 票である。集計や統計值の算出には SPSS を用いた。
表 1 調查対象の概要

\begin{tabular}{c|l|r|r|l|}
\hline 大学名 & 所属学科・専攻 & 票数 & $\begin{array}{c}\text { 構成比 } \\
(\%)\end{array}$ & 備 考 \\
\hline A大学 & 食物系 $/$ 家政系 & 72 & 50.7 & 2回生以上8票 \\
\hline B大学 & 家政教育系 & 32 & 22.5 & 2回生以上13票 \\
\hline C大学 & 住居系 & 38 & 26.8 & \\
\hline \multicolumn{2}{c|}{ 合 計 } & 142 & 100.0 & \\
\hline
\end{tabular}

\section{（2）調査対象者の回答者としての特性}

今回の調査対象である家政学・生活科学系の大学生は、おおよそ 次のような特徽を持っていると整理できる。一つは、大学生である ことから学校教育で学んできた家庭科の内容の総括ができること、 二つは、家政・生活科学系の学生であることから住生活や住教育に は比較的関心があると想定でき、調查内容の理解度と回答意欲があ る程度期待できること、三つ目に、回答者の専攻やコースが食物系・ 家政教育系・住居系、などと異なることから、専門性による違いの 検証もできること、である。

今回の調查対象者は、高校までの住居領域学習経験は他分野の大 学生と同等であると思われるが、もともと家庭科分野や住居領域一 の関心が強い学生が多いと位置づけられる。さらに家政教育・住居 系の学生は大学入学後に多少なりとも住居領域の講義を受けていて、 それが学習志向の回答に若干の影響を与えていると予想される。そ のため本論では、住居領域に比較的近い領域のなかでも異なる専門 領域で学ぶ学生間にどのような差違や多様性があるかの検討を行う こととなる。

他の専門領域の学生を調查した場合、関心が薄いことにより回答 数が少なくなるなど、希釈的となる可能性が想定される。その点を 考慮するならば本アンケート調查の回答者の構成は、住居領域にや や偏りをもつことで、住居領域への学習者の意識の特徽や傾向をよ り強く、あるいは凝縮して把握できると考えた。それによる限界や 偏りを踏まえる必要はあるが、住生活に興味を持たない学生を含む 広範な分野の学生を今後検討するためにも有益であると位置づけて いる。

\section{（3） 調査票の概要}

調查票の質問項目は、これまで学んできた住居領域の学習内容と、 現在学びたい学習内容を中心に、基本属性（性別や出身地など）、出 身高校の学校条件と家庭科履修状況、住宅や住まい方についての考 え方（住意識）や住生活に関わる日常行動などを尋ねている。

本研究ではこのうち、学生が学びたいと思う学習内容に焦点を当 てた分析を行った。

\section{3. 調査対象の特性 \\ （1）対象者の基本属性}

対象学生の性別は、男子学生が $18.6 \%$ 、女子学生が $81.4 \%$ で、ほ ぼ 2 対 8 の割合である。そのため、回答の全体傾向は女子学生の意 見が反映されることになる。

出身地では大阪府 $(54.5 \%)$ が半数以上で最も多く、兵庫県や和 歌山県などを合わせた近畿圏出身の学生で $87.1 \%$ を占める。調査対 象とした大学は大阪府内にあるため地元から通う学生が多く、自宅 から通う学生は $76.3 \%$ で下宿生は 4 分の 1 程度である。

現在所属している学部・学科別では食物系が 5 割弱、家政教育系 
と住居系がそれぞれ同割合に分かれている。これらを学生の専門性 と位置づけて、それと学習志向との関連性についてもみていくこと にする。ただし、A 大学の家政教育系は 8 名のため、専門性の分類 においては除外することにした。

\section{表 2 対象者の個人条件}

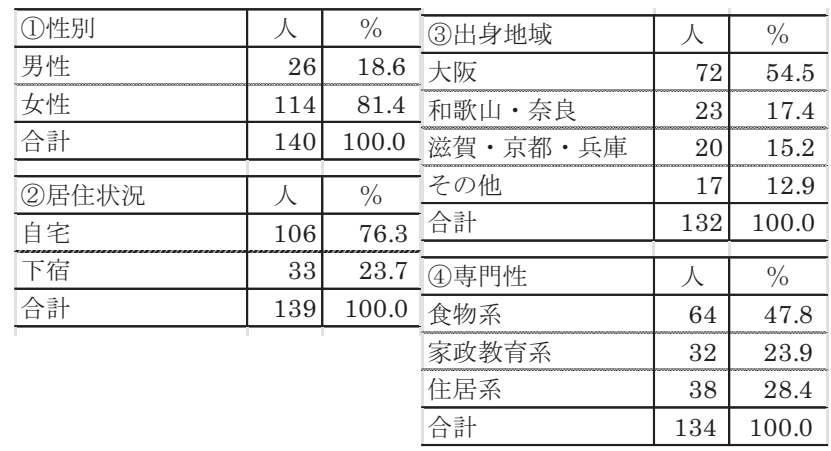

\section{（2）出身高校と高校までの住居領域学習経験の有無}

\section{(1) 出身高校と家庭科の履修科目}

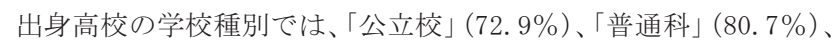
「共学校」 $(88.6 \%)$ がそれぞれ多くみられる。高校での家庭科履修 科目では「家庭総合」が $42.0 \%$ で最も多く、「家庭基礎」(26.1\%)

\section{表 3 出身高校の学校種}

\begin{tabular}{l|r|r}
\hline & \multicolumn{1}{|c|}{ 人 } & \multicolumn{1}{c}{$\%$} \\
\hline 普通科 & 113 & 80.7 \\
\hline その他 & 27 & 19.3 \\
\hline 合計 & 140 & 100.0 \\
\hline \hline & \multicolumn{1}{|c|}{ 人 } & \multicolumn{1}{c|}{$\%$} \\
\hline 公立 & 102 & 72.9 \\
\hline 私立 & 38 & 27.1 \\
\hline 合計 & 140 & 100.0 \\
\hline \hline & \multicolumn{1}{|c|}{ 人 } & \multicolumn{1}{c|}{$\%$} \\
\hline 共学校 & 124 & 88.6 \\
\hline 男子校 & 1 & 0.7 \\
\hline 女子校 & 14 & 10.0 \\
\hline その他 & 1 & 0.7 \\
\hline 合計 & 140 & 100.0 \\
\hline
\end{tabular}

表 4 高校家庭科の履修科目

\begin{tabular}{l|r|r}
\hline & \multicolumn{1}{|c|}{} & \multicolumn{1}{c}{$\%$} \\
\hline 家庭基礎 & 36 & 26.1 \\
\hline 家庭総合 & 58 & 42.0 \\
\hline 生活技術 & 2 & 1.4 \\
\hline その他 & 7 & 5.1 \\
\hline 覚えていない & 35 & 25.4 \\
\hline 合計 & 138 & 100.0 \\
\hline
\end{tabular}

の履修学生を上回っている。家庭総 合は原則 4 単位であるため、前者の 学生は 2 年間かけて家庭科を学んで きたと想定できる。一方、科目名を 「覚えていない」学生は $25.4 \%$ 存在 している。この回答者の大半が原則 1 単位で 1 年間の授業となる「家庭基礎」を履修してきた場合には、 家庭科の時間数が少なかった学生がより多い可能性はある。

この履修科目を学生の専門性別でみると (図 1)、今回の調查対象

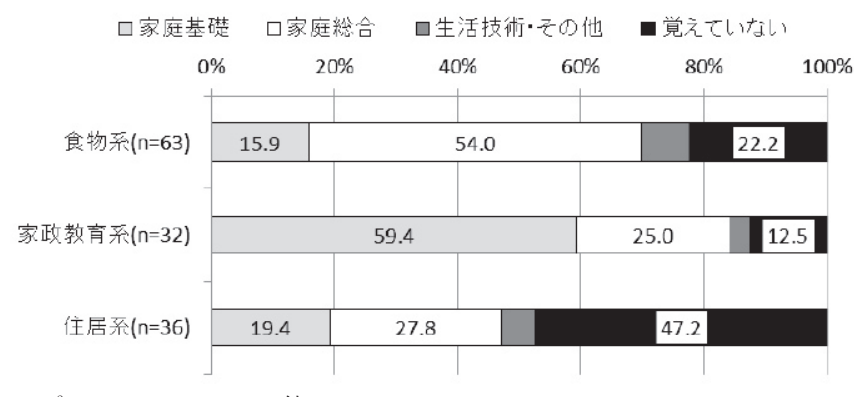

$\chi^{2}=31.43 \quad \mathrm{df}=6 \quad \mathrm{P}$ 值 $=0.000$

図 1 学生の専門性別、家庭科の履修科目
者の食物系では家庭総合、家政教育系では家庭基礎の履修学生がそ れぞれ多くみられた。住居系の学生は科目名を記憶していない者が 多く、家庭科そのものには関心が低い学生が多いことが考えられる。

\section{(2) 住居領域の学習経験の有無}

高等学校までに住居領域の学習を授業で受けて学んできたかとの 問いで、住居領域の学習経験の有無を尋叔たところ、「学んだ」と答 えた者は $53.9 \%$ （76 人）で半数強であった(図 2)。また、「覚えて いない」者は $29.8 \%$ (42 人)、「学んでいない」者は $16.3 \%$ (23 人) みられた。学校教育での住教育は主に家庭科の一領域に位置づけら れているため、本来は小・中・高校を通して住居領域を学習してい るはずである。しかし本調査からは、回答者の意識として学習した との明確な意識がないものと見られる。対象学生が実際にどんな授 業を受けてきたかが定かではないが、結果をみるかぎり教育現場で の住居領域学習が充実しているとは言い難いと指摘できよう。

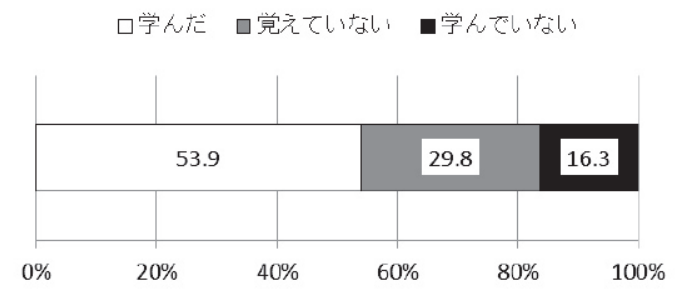

図 2 これまでの学校での住居領域学習経験の有無 $(\mathrm{n}=141)$

また、学生の専門性別では、食物系と住居系に 6 割ずつ住居領域の 学習経験者がおり、家政教育系では覚えていない・学んでいないが 7 割強となっている(図 3)。この住居領域学習経験は小・中・高含めて 尋衩たものであるが、直近の高等学校の記憶が回答に影響を与える と考えられる。有意差はないものの、家庭基礎を学んできた学生は家 庭総合の学生よりも住教育を「学んだ」との回答率が低い傾向にあ る(図 4)。

これらを踏まえると、食物系は家庭科を比較的充実して学んでき ており住居領域学習経験もある集団、家政教育系は家庭科について は基礎的な内容を学び、住居領域学習については学習経験不明者と 未学習者が多い集団、そして住居系は家庭科の記憶は不明確だが住 居領域の学習経験者が多く、住に関する専門性を高めようとしてい る集団、ということができそうである。

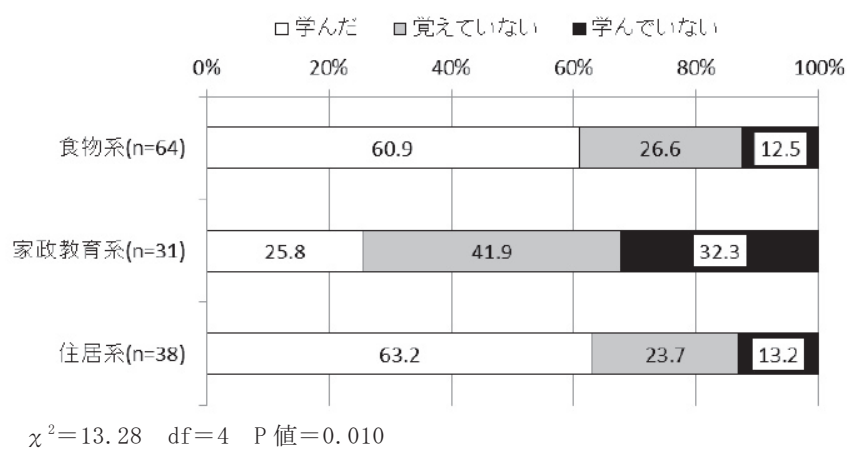

図 3 学生の専門性別、住居領域学習経験 


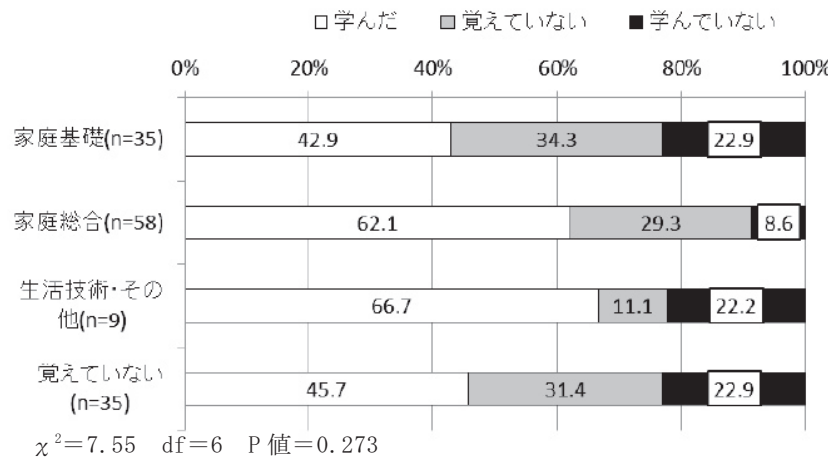

図 4 家庭科の履修科目別、住居領域学習経験

\section{5. 学んだ学習内容の特性}

\section{(1) 設問項目と学習指導要領の内容}

アンケートに記載した「住生活に関する学習内容」の 18 項目は、 現・旧の家庭科の学習指導要領解説に挙げられた項目の他、対応す る教科書に記載されている項目、及び過去の類似研究で取り上げら れた項目を参考として整理した。これらの項目は、著者がキーワー ドを「学習内容」と「学習目的」とを分離して検討したように (2011 年日本家政学会大会）学習指導要領のなかでも複雑な重層性をもっ ている。また高校教科書でさまざまの形で扱われており、例えば「住 居の計画」で記述される内容は「家族の生活」などに及ぶ場合もあ り、また逆に「家族の生活」のなかで「住居の計画」に言及するこ ともあるなど、教科書によって多様である。それらの項目は場合に よっては包含関係にある場合もあるが、別の文脈ではまた異なる関 係があり得る。

一方学習者をみるならば、項目を体系的に理解していると想定す ることは困難であり、一般的、常識的な項目として提示する方が回 答しやすいと判断される。そうしたことを考慮して提示したもので あるため、今回の 18 項目は試行的な面があるが、回答結果を総合 的にみることで一定の方向性が見いだせると考えた。回答された項 目の関係性を整理する中で、新たな枠組みを検討することにしたい。

なお、小・中・高等学校の家庭科の現行学習指導要領 (小・中学 校は平成 10 年、高等学校は平成 11 年に告示) と学習指導要領解説 の記述に、各項目に対応するキーワードが記載されている場合には の印を、ほぼ対応していると判断した場合には○印をつけている。 「住宅問題」などは指導要領の文言にはなく一部の教科書では記載の ある内容であるが、この表では無印とした(表 5)。

\section{(2) 学んだ学習内容の全体的傾向}

「高等学校までに学んだ内容」を、学習経験者 $(76$ 人) に 18 項目 から複数回答で選択してもらった。この、学んだ内容とは主観的な 回答であり、小・中・高を通して過去に学んだと記憶している内容 ともいえる。すなわち、実際にその内容を学んだかどうかは定かで はなく、印象に残っている学習内容を挙げていることになる。また、 選択された複数項目は、実際に学んだ内容であっても同時期に学ん だものとはいえず、現段階で蓄積され小学校から高校までに「学ん だ」と認識している内容であることを述べておきたい。

学んだ内容の上位項目は、「住まいの機能・役割」(84.2\%)や「気 候・風土と住まい」 $(73.7 \%)$ が 7 ～割以上で学習率が高く、「室
内環境（音・光・風・熱）」 $(63.2 \%)$ や「家族の生活と住居・住空 間」 $(57.9 \%) 、 「$ 住居の計画（間取り・平面計画）」(50.0\%) が 5 〜 6 割で続き、「家庭内事故やその防止」（39.5\%）も相対的には高い 学習率である。上位項目の共通点は、家庭科の学習指導要領に記載 があることだが、「小・中・高」や「中・高」に連続して位置づけら れている内容に学習率が高いといえる。

表 5 学生が「学んだ」住生活の学習内容（複数回答）

\begin{tabular}{|c|c|c|c|c|c|c|c|c|}
\hline & \multirow{2}{*}{\multicolumn{3}{|c|}{$\begin{array}{l}\text { 「学んだ」の } \\
\text { 回答数と比率 }\end{array}$}} & \multicolumn{4}{|c|}{$\begin{array}{l}\text { 参考: 学習指導 } \\
\text { 要領の記述 }\end{array}$} \\
\hline & & & & & \multirow{2}{*}{\begin{tabular}{|l|} 
小 \\
\\
家 \\
庭
\end{tabular}} & \multirow{2}{*}{\begin{tabular}{|c|} 
中 \\
技 \\
術 \\
$\cdot$ \\
家 \\
庭 \\
\end{tabular}} & \multicolumn{2}{|c|}{ 高 } \\
\hline & & $\%$ & $\begin{array}{l}\text { 度 } \\
\text { 数 }\end{array}$ & $\begin{array}{l}\text { 順 } \\
\text { 位 }\end{array}$ & & & $\begin{array}{c}\text { 家 } \\
\text { 庭 } \\
\text { 基 } \\
\text { 礎 }\end{array}$ & $\begin{array}{l}\text { 家 } \\
\text { 庭 } \\
\text { 総 } \\
\text { 合 }\end{array}$ \\
\hline & 住まいの機能・役割 & 84.2 & 64 & 1 & 0 & 0 & 0 & 0 \\
\hline & 気候・風土と住まい & 73.7 & 56 & 2 & & 0 & & 0 \\
\hline & 住まいの歴史 & 13.2 & 10 & 16 & & & & \\
\hline 4 & 家族の生活と住居・住空間 & 57.9 & 44 & 4 & 0 & 0 & - & 0 \\
\hline & 住居の計画（間取り・平面計画） & 50.0 & 38 & 5 & & & 0 & 0 \\
\hline & 住居の設計 （製図・住宅模型） & 19.7 & 15 & 11 & & & & \\
\hline & 室内環境（音・光・風・熱） & 63.2 & 48 & 3 & ○ & - & 0 & - \\
\hline 8 & 身の回りの整理・整頓 & 32.9 & 25 & 7 & 0 & & & \\
\hline 9 & 住まいの清掃と手入れ & 27.6 & 21 & 10 & 0 & 0 & & \\
\hline 10 & 自然災害に備えた住まい方 & 32.9 & 25 & 7 & & & 0 & $\bullet$ \\
\hline 11 & 家庭内事故やその防止 & 39.5 & 30 & 6 & & 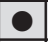 & 0 & $\bullet$ \\
\hline 12 & 住居の維持管理 & 6.6 & 5 & 17 & & & 0 & - \\
\hline 13 & インテリア計画 & 15.8 & 12 & 13 & & & & \\
\hline 14 & 住宅の選び方や買い方・借り方 & 14.5 & 11 & 15 & & & 0 & 0 \\
\hline 15 & 住宅問題 & 30.3 & 23 & 9 & & & & \\
\hline 16 & 住宅政策 & 6.6 & 5 & 17 & & & & \\
\hline 17 & 環境共生の住まいや住まい方 & 15.8 & 12 & 13 & & & & 0 \\
\hline 18 & 居住地環境とまちづくり & 19.7 & 15 & 11 & & & 0 & 0 \\
\hline & 合計 & 100.0 & 76 & 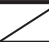 & $Z$ & 7 & & 7 \\
\hline
\end{tabular}

注 1) 全体の上位 (各項目回答率の平均 $33.6 \%$ 以上) の項目は網がけ で表している。

注 2）学習指導要領解説の記述に対応寸るキーワードが記載されて

いる場合はの印、ほぼ対応している場合には○印をつけている。

一方、下位項目には学習率が 1 割にも満たない項目として「住居 の維持管理」「住宅政策」(6.6\%) があり、「住まいの歴史」(13.2\%) なども学習されてきていない。下位項目は、学習指導要領や解説の 文中ではその文言が登場しないが、一部の教科書に内容が組み込ま れているようなものである。ただ、「維持管理」は高校の家庭基礎・ 家庭総合のいずれの指導要領にも「計画的な維持管理」として設定 されている。おそらく実際の指導率が低く、教員が指導困難性を持 ちやすい内容であると思われる。全体的には住まいの社会性に関わ る内容が下位に位置する傾向にあるといえる。

\section{(3) 学んだ学習内容の組み合わせ}

学んだ学習内容には組み合わせがある、との仮説をたてて、学習 内容 18 項目に主成分分析（主成分法、バリマックス回転）を行っ た。その結果、全体で 5 割弱を説明する 5 つの成分を得た(表 6)。

第 1 成分において負荷量が高い項目は、0.6 以上では「住宅問題」 (0.812)、「環境共生の住まいや住まい方」 $(0.738)$ 、「家庭内事故や その防止」(0.610)の 3 項目で、「自然災害に備えた住まい方」(0.474) が続く。「住宅問題」は見方によっては総合性が高いが、第 1 成分 はどちらかといえばトピック的で up-to-date 的なテーマであり、い 
ずれも問題解決を指向するテーマを持つ学習内容といえる。これら を中心に学んできた回答を「住居の問題・トピック」型とする。

第 2 成分は「住まいの清掃と手入れ」(0.815)、「身のまわりの整 理・整頓」(0.751)、「住居の維持管理」（0.635）の項目である。「住 居の維持管理」の示寸学習範囲は広概念ではあるが、住居を衛生・ 安全面も含めて快適にするための処置・作業の方法や技術に関する 内容とみなし、「住居・室内の維持管理」型と寸る。第 3 成分では 「住居の計画（間取り・平面計画）」（0.808）、「住居の設計（製図、 住宅模型 $) 」(0.773)$ の主成分負荷量が高いため「住居の計画・設 計」型、第 4 成分での「住まいの機能・役割」(0.677)、「気候・風 土と住まい」（0.635）、「室内環境（音・光・風・熱）」（0.616）は、 住居の基本的性質を学ぶ内容であることから「住居の原論」型と呼 ぶことにする。また、第 5 成分は「インテリア計画」(0.741) の項 目のみが際立っているため、そのまま「インテリア」型とする。

実際に学んだ学習内容の組み合わせはあくまで回答者の記憶によ るものだが、見方を変えると教える側にとって、各成分内に配され た学習内容項目のそれぞれは授業時に連動させやすい内容とも読み 取れるだろう。

表 6 学んだ学習内容の主成分分析結果 (バリマックス回転)

\begin{tabular}{|c|c|c|c|c|c|c|}
\hline & \multicolumn{5}{|c|}{ 回転後の成分行列 } & \multirow{2}{*}{$\begin{array}{l}\text { コミュ } \\
\text { ナリテ } \\
\text { 1 }\end{array}$} \\
\hline & $\begin{array}{l}\text { 第 } 1 \\
\text { 成分 }\end{array}$ & $\begin{array}{l}\text { 第 } 2 \\
\text { 成分 }\end{array}$ & $\begin{array}{l}\text { 第 } 3 \\
\text { 成分 }\end{array}$ & $\begin{array}{l}\text { 第 } 4 \\
\text { 成分 }\end{array}$ & $\begin{array}{l}\text { 第 } 5 \\
\text { 成分 }\end{array}$ & \\
\hline 住まいの機能・役割 & 0.037 & -0.103 & -0.101 & 0.677 & 0.088 & 0.553 \\
\hline 気候・風土と住まい & 0.362 & 0.205 & -0.111 & 0.635 & -0.093 & 0.635 \\
\hline 住まいの歴史 & 0.137 & 0.188 & -0.006 & 0.121 & 0.216 & 0.791 \\
\hline 家族の生活と住居・住空間 & -0.076 & 0.237 & -0.342 & 0.202 & 0.481 & 0.734 \\
\hline 住居の計画 (間取り·平面計画) & -0.003 & -0.011 & 0.773 & -0.237 & 0.198 & 0.707 \\
\hline 住居の設計（製図·住宅模型） & 0.061 & 0.031 & 0.808 & 0.298 & 0.023 & 0.769 \\
\hline 室内環境（音·光·風·熱） & -0.062 & 0.064 & 0.167 & 0.616 & 0.099 & 0.451 \\
\hline 身の回りの整理・整頓 & 0.125 & 0.751 & 0.083 & -0.052 & 0.015 & 0.635 \\
\hline 住まいの清掃と手入れ & 0.202 & 0.815 & -0.105 & 0.027 & 0.083 & 0.737 \\
\hline 自然災害に備えた住まい方 & 0.474 & -0.154 & -0.062 & 0.127 & 0.595 & 0.666 \\
\hline 家庭内事故やその防止 & 0.610 & 0.167 & 0.004 & 0.137 & 0.242 & 0.826 \\
\hline 住居の維持管理 & 0.004 & 0.635 & 0.042 & 0.235 & 0.060 & 0.675 \\
\hline インテリア計画 & -0.011 & 0.057 & 0.332 & -0.181 & 0.741 & 0.721 \\
\hline $\begin{array}{l}\text { 住宅の選び方や買い方・借り } \\
\text { 方 }\end{array}$ & -0.006 & 0.114 & 0.059 & 0.259 & 0.523 & 0.408 \\
\hline 住宅問題 & 0.812 & 0.204 & 0.119 & 0.055 & 0.009 & 0.737 \\
\hline 住宅政策 & 0.273 & 0.377 & 0.284 & 0.094 & -0.106 & 0.686 \\
\hline 環境共生の住まいや住まい方 & 0.738 & 0.115 & -0.027 & -0.004 & 0.003 & 0.635 \\
\hline 居住地環境とまちづくり & 0.221 & 0.053 & 0.108 & 0.095 & 0.115 & 0.654 \\
\hline $\begin{array}{l}\text { 寄与率 } \\
\end{array}$ & 11.915 & 11.371 & 9.244 & 9.203 & 8.973 & \\
\hline
\end{tabular}

\section{6. 学びたい学習内容の特性}

アンケートでは学びたい学習内容を答えさせたが、学んでいない 内容についての知識は乏しいはずであり、学びたいかどうかは答え にくいと考えられる。しかし一方で、新聞、その他からの一般的な 知識をもっている可能性もある。そこでこの 6 章では、「学びたい 学習内容」について学習経験の有無を度外視して概括的な分析を行 い７章で、まず住居領域を学んだ（ことを記憶している）回答者 と学んでいない（と意識している）回答者に分けて検討を行い(図 5)、次いで個々の項目について学んだ（と意識している）回答者の 学びたいと思っている比率の検討を行った（図 6)。

\section{（1）学びたいと思う学習内容の全体的傾向}

現在の学習希望について「住生活の学習でどんな内容を学びたい ですか」と尋ね、複数回答で答えてもらった(表 7 )。最も学習希望 が高い項目は「インテリア計画」 $(68.3 \%)$ で 7 割近くみられ、次 に 2 割近く低下して「住宅の選び方や買い方・借り方」(47.2\%) が挙がっている。先行調査と同様にインテリアの人気は不動である が、住宅選択についても比較的高い関心が抱かれていることがわか る。いずれも近未来に役立つ展望的で具体的な内容であり、これか らの実生活に関連づけやすい学習内容と捉えられる。

表 7 学生が「学びたい」住生活の学習内容（複数回答）

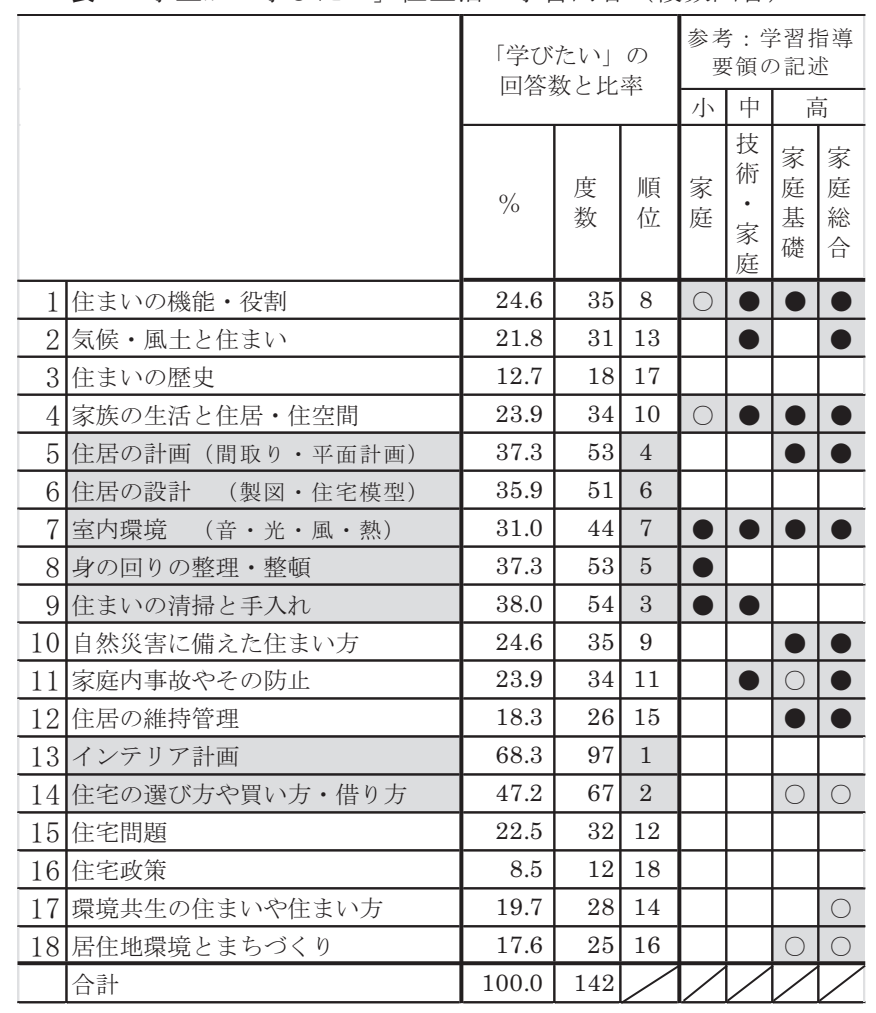

注）全体の上位（各項目回答率の平均 $28.5 \%$ 以上）の項目は網がけ で表している。

注 2) 学習指導要領解説の記述に対応寸るキーワードが記載されて

いる場合は・印、ほぼ対応している場合には○印をつけている。

また、3〜4 割近くみられて相対的に学習希望の高い項目は、住 居の「計画」・設計」に関する内容や、「室内環境」・「空間の管理」 に関する内容である。こうしてみると、全体的には住宅や住空間に 直接関与寸るような学習内容に関心が高いことがうかがえる。

他方、下位項目は「住宅政策」(8.5\%) や「住まいの歴史」(12.7\%) 等であり、学習希望者は 1 割前後にとどまっている。過去の学習経 験等の意識への影響を度外視してこれらに共通する性質は、社会・ 経済・歴史等に関する知識を有することで理解が深まるような、換 言すれば、学習者に社会科学的な素養がなければ理解しづらいよう な内容ということであろう。また、学んだことが今日、明日の住生 活にすぐ活かされるというものではなく、やや抽象的な内容ともい えそうである。

\section{（2）学習の志向性}

前述の単純集計結果からは学びたい内容の全体的傾向が把握でき たが、先の学んだ内容と同様に、学生が学びたいと思う学習内容の 
選び方にもタイプがある、との仮説をたてて学習内容 18 項目に因 子分析（主因子法、バリマックス回転）を行った。その結果、ここ でも全体で 5 割弱を説明する 5 つの因子を得た(表 8)。

第 1 因子は「住まいの機能・役割」(0.674)、「住まいの歴史」(0.628)、 「気候・風土と住まい」（0.563）の項目で、共通要素からは「住居 の原論・住文化」への関心の高さを表す因子であると考えられる。

こうした因子を以下、学習志向性と呼ぶことにする。

第 2 因子では「居住地環境亡まちづくり」(0.786)、「環境共生の 住まいや住まい方」（0.680）の因子負荷量が高く、住まいを取り巻 く自然と社会環境も含めた広概念の「住環境」の学習志向性とみら れる。

第 3 因子では「住宅の選び方や買い方・借り方」(0.582)、「住宅 政策」（0.559）といった項目で、これらには住まいの社会的側面が 関連することから「住居と社会」の学習志向性と位置づけた。

また、第 4 因子は「住居の計画」(0.817)、「住居の設計」(0.729) の項目から「住居の計画・設計」の学習志向性、第 5 因子は「住ま いの清掃と手入れ」(0.694)、「身の回りの整理・整頓」（0.529）の 項目から「室内の維持管理」の学習志向性と捉えることにした。

先でみた学んだ内容と組み合わせは類似しているが、新たな要素 が関連するなどの違いがある。例えば、住まいの機能・役割や気候・ 風土との関係を学びたい者は、学んだ内容では関連性の低かった住 まいの歴史という文化的側面にも興味を示しているともみられる。

表 8 学びたい学習内容の因子分析結果

（主因子法、バリマックス回転）

\begin{tabular}{|c|c|c|c|c|c|c|}
\hline & \multicolumn{5}{|c|}{ 因子負荷量 } & \multirow{2}{*}{$\begin{array}{l}\text { コミュ } \\
\text { ナリテ } \\
1\end{array}$} \\
\hline & $\begin{array}{l}\text { 第 } 1 \\
\text { 因子 }\end{array}$ & $\begin{array}{l}\text { 第 } 2 \\
\text { 因子 }\end{array}$ & $\begin{array}{l}\text { 第 } 3 \\
\text { 因子 }\end{array}$ & $\begin{array}{l}\text { 第 } 4 \\
\text { 因子 }\end{array}$ & $\begin{array}{l}\text { 第 } 5 \\
\text { 因子 }\end{array}$ & \\
\hline 住まいの機能・役割 & 0.674 & 0.103 & 0.091 & 0.113 & 0.159 & 0.511 \\
\hline 気候・風土と住まい & 0.563 & 0.344 & 0.097 & 0.147 & 0.077 & 0.473 \\
\hline 住まいの歴史 & 0.628 & 0.058 & 0.360 & 0.061 & 0.006 & 0.531 \\
\hline 家族の生活と住居・住空間 & 0.252 & 0.173 & 0.251 & 0.249 & 0.133 & 0.236 \\
\hline 住居の計画（間取り•平面計画） & 0.183 & 0.018 & -0.012 & 0.817 & 0.075 & 0.707 \\
\hline 住居の設計（製図·住宅模型） & 0.141 & 0.083 & 0.106 & 0.729 & -0.014 & 0.569 \\
\hline 室内環境（音·光·風·熱） & 0.403 & 0.329 & 0.113 & 0.307 & 0.264 & 0.448 \\
\hline 身の回りの整理・整頓 & 0.086 & 0.023 & 0.132 & 0.078 & 0.529 & 0.311 \\
\hline 住まいの清掃と手入れ & 0.141 & 0.075 & 0.123 & 0.056 & 0.694 & 0.526 \\
\hline 自然㷋害に備えた住まい方 & 0.285 & 0.260 & 0.392 & 0.147 & 0.294 & 0.411 \\
\hline 家庭内事故やその防止 & 0.110 & 0.216 & 0.446 & 0.059 & 0.312 & 0.358 \\
\hline 住居の維持管理 & 0.272 & 0.322 & 0.363 & -0.015 & 0.254 & 0.375 \\
\hline インテリア計画 & -0.114 & 0.126 & 0.074 & 0.305 & 0.209 & 0.171 \\
\hline $\begin{array}{l}\text { 住宅の選び方や買い方・借り } \\
\text { 方 }\end{array}$ & 0.067 & -0.145 & 0.582 & 0.072 & 0.285 & 0.451 \\
\hline 住宅問題 & 0.359 & 0.122 & 0.415 & -0.055 & 0.135 & 0.337 \\
\hline 住宅政策 & 0.150 & 0.271 & 0.559 & 0.143 & -0.083 & 0.436 \\
\hline 環境共生の住まいや住まい方 & 0.225 & 0.680 & 0.079 & 0.032 & 0.249 & 0.582 \\
\hline 居住地環境とまちづくり & 0.140 & 0.786 & 0.179 & 0.191 & -0.092 & 0.715 \\
\hline $\begin{array}{lc}\text { 寄与率 } \\
\end{array}$ & 10.442 & 9.488 & 8.993 & 8.812 & 7.529 & \\
\hline
\end{tabular}

\section{（3）基本属性と学習志向性の関係}

\section{(1)男女別に見た学習希望の項目}

学びたいと思う学習内容、すなわち学習希望の項目選択において、 性別による回答傾向の差違を検討するために、「学びたい」を 1 と し無回答を 0 として平均值を求め、その平均值の男女差の妥当性に ついては、 $\mathrm{t}$ 検定により検定した。なおその平均值は「学びたい」
の回答比率にもなるので表 9 では\%の表示にしている。

有意性が認められた項目は各 2 項目あり、男子学生に回答が多い 項目は「住まいの機能・役割」 $\left(\mathrm{t}=2.818^{* *}\right)$ と「室内環境」 $\left(\mathrm{t}=2.286^{*}\right)$ で、女子学生では「住宅の選び方や買い方・借り方」 $\left(\mathrm{t}=-2.865^{* *}\right)$ と「家族の生活と住居・住空間」（t=-2.209*) である。その他にも、 有意ではないが男子学生に支持が多い項目には「住居の計画」や「住 居の設計」があり、女子学生の場合は「身の回りの整理・整頓」「住 まいの清掃と手入れ」がある。

表 9 男女別の学びたい学習内容と平均値の比較 ( $\mathrm{t}$ 検定)

\begin{tabular}{|l|r|r|r|r|}
\hline & $\begin{array}{c}\text { 男性 } \\
(26 \text { 人) }\end{array}$ & $\begin{array}{c}\text { 女性 } \\
(114 \text { 人) }\end{array}$ & $\mathrm{t}$ 值 & $\begin{array}{c}\text { 有意 } \\
\text { 確率 } \\
\text { (両側 }\end{array}$ \\
\hline 住まいの機能・役割 & $46.2 \%$ & $20.2 \%$ & 2.818 & 0.006 \\
\hline 気候・風土と住まい & $26.9 \%$ & $21.1 \%$ & 0.647 & 0.519 \\
\hline 住まいの歴史 & $11.5 \%$ & $13.2 \%$ & -0.221 & 0.825 \\
\hline 家族の生活と住居・住空間 & $7.7 \%$ & $28.1 \%$ & -2.209 & 0.029 \\
\hline 住居の計画 (間取り·平面計画) & $53.8 \%$ & $34.2 \%$ & 1.873 & 0.063 \\
\hline 住居の設計 (製図·住宅模型) & $50.0 \%$ & $32.5 \%$ & 1.690 & 0.093 \\
\hline 室内環境 (音·光·風·熱) & $50.0 \%$ & $27.2 \%$ & 2.286 & 0.024 \\
\hline 身の回りの整理・整頓 & $23.1 \%$ & $40.4 \%$ & -1.649 & 0.101 \\
\hline 住まいの清掃と手入れ & $26.9 \%$ & $41.2 \%$ & -1.351 & 0.179 \\
\hline 自然㷋害に備えた住まい方 & $11.5 \%$ & $28.1 \%$ & -1.764 & 0.080 \\
\hline 家庭内事故やその防止 & $11.5 \%$ & $27.2 \%$ & -1.685 & 0.094 \\
\hline 住居の維持管理 & $7.7 \%$ & $21.1 \%$ & -1.584 & 0.116 \\
\hline インテリア計画 & $11.5 \%$ & $7.9 \%$ & 0.595 & 0.553 \\
\hline 住宅の選び方や買い方・借り方 & $23.1 \%$ & $53.5 \%$ & -2.865 & 0.005 \\
\hline 住宅問題 & $11.5 \%$ & $21.9 \%$ & -1.193 & 0.235 \\
\hline 住宅政策 & $23.1 \%$ & $16.7 \%$ & 0.766 & 0.445 \\
\hline 環境共生の住まいや住まい方 & & & & $\mathrm{f}=138$ \\
\hline 居住地環境とまちづくり & $19.2 \%$ & $71.9 \%$ & -1.800 & 0.074 \\
\hline
\end{tabular}

総括すると、男子学生は住居の「原論」や「計画・設計」など 住宅そのものへの関心が高いのに対し、女子学生の場合は「暮ら し」や「室内」など住生活の内容や現実的な営みへの関心が高い と思われる点が注目できる。こうした傾向の背景には、学生が育 ってきた家庭環境や社会生活において遭遇するジェンダー的な要 素が影響していることも想定される。

\section{(2)専門性別にみた学習志向性}

学生が現在所属している学科や専攻である食物系・家政教育 系・住居系を学生の専門性とみなし、この専門性別に主因子法で の因子得点の平均の比較を行った(表 10)。平均值が相対的に大き いほど、その学習志向性を代表する項目を「学びたい」と回答した 傾向にあるとみることができる。

最も顕著に表れているのが住居系学生で、「住居の計画・設計」 （0.404）と「住環境」（0.301）の学習志向性が高いことがわかる。 あとの二者では顕著ではないが、家政教育系では「住居と社会」 (0.168) と「室内の維持管理」（0.158）、食物系では「室内の維持 管理」（0.064）の学習志向性において、わずかに高い傾向にあり、 
大学入学後に住居領域に関する専門教育を受けたことの影響が、き わめて弱いものの少しはあるとみられる。家政教育系の場合は家庭 科教員を目指している学生が多いことから家庭生活への問題意識が 高いと思われ、幅広い視点と内容を含む「住居と社会」の学習志向 性が二者よりも高いと考えられる。

このように、現在の専門性に比較的近い内容について関心を抱い ていることから、学生にとって直接的な関心事が学習志向性に反映 することが読み取れる。加えて、本調查の回答の信頼性が反映され たとみることができるだろう。

表 10 専門性別にみた主因子得点の平均

\begin{tabular}{|l|l|r|r|r|}
\hline \multicolumn{2}{|l|}{} & \multicolumn{1}{|c|}{$\begin{array}{c}\text { 食物系 } \\
(64 人)\end{array}$} & $\begin{array}{c}\text { 家政教育系 } \\
(32 \text { 人) }\end{array}$ & \multicolumn{1}{c|}{$\begin{array}{c}\text { 住居系 } \\
(38 \text { 人) }\end{array}$} \\
\hline 第1因子 & 住居の原論・住文化 & -0.0483 & -0.0846 & -0.0522 \\
\hline 第2 因子 & 住環境 & -0.0870 & -0.1362 & 0.3012 \\
\hline 第 3 因子 & 住居と社会 & -0.1120 & 0.1676 & 0.0213 \\
\hline 第4 因子 & 住居の計画・設計 & -0.2028 & -0.0836 & 0.4042 \\
\hline 第 5 因子 & 室内の維持管理 & 0.0642 & 0.1575 & -0.2649 \\
\hline
\end{tabular}

\section{7. 学習経験と学びたい学習内容の関係}

\section{(1) 学習経験の有無と学びたい内容}

学生が学びたい内容と学習経験は関連しているのだろうか。学ん だ内容と単純に並べて比較することはできないが、全体の傾向を把 握するために見比べてみると、例えば「住まいの機能・役割」「気候・ 風土と住まい」などの学んだ内容における上位項目は学びたい内容 では低下し、「インテリア計画」「住宅の選び方や買い方・借り方」 などはその逆である。一方、「住居の計画」は学んだ割合も、学びた い内容での支持率も相対的に高い。このようにみると、学習内容に よって学習経験の有無が関連するものとしないものがある、との特 徵が見いだせると考えられた。

そこで最初に、住居領域を「学んだ人」(学習経験者) と「学んで いない・覚えていない人」(未学習者・学習不明者) 別に、学びたい 内容の項目選択に違いがあるかをみることにした(図 5)。

結論から述べると、両者の項目選択に有意な差はみられなかった が、ある程度の傾向特性はあると思われた。学習経験の有無を問わ ず支持のある学習内容は「インテリア計画」で 7 割近くみられ、一 方で 1 割前後と低率なのは「住宅政策」「住まいの歴史」である。身 近で気軽に取り組める分かりや寸そうなテーマか否かという点は、 学習経験の有無に関わらず共通の指標であるかもしれない。

また、全体では未学習者・学習不明者ほど各項目を学びたいと積 極的に選択している傾向がみえる。特に「気候・風土」や「室内環 境」など住居の原論に近い基本的内容についての学習希望率が高い。 学習経験者では「環境共生」や「維持管理」「自然災害」と住まいに 関わる項目を選んでおり、住居の問題・トピックや住環境といった、 幅広い知識や背景に対する深い理解を要する学習内容を選択してい るように思われる。

\section{(2) 学んだ内容についての再学習希望率}

次に、「学んだ人」に注目し、各項目の再学習希望率をみる。ある 学習内容を学んだ人が、その同じ内容を再び学びたいと思っている かをみたもので、例えば「住まいの機能・役割」は学習経験のある 76 人中の 64 人となる $84.2 \%$ の人か「学んだ」内容であるが、その

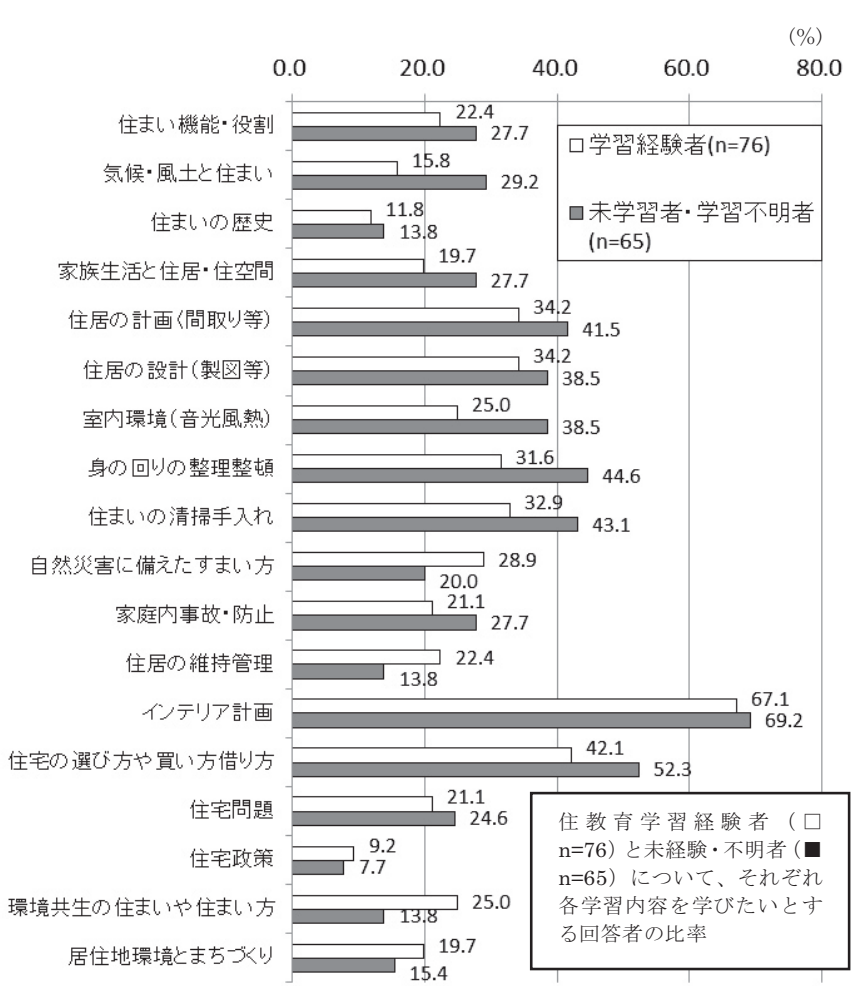

図 5 住居領域学習経験の有無別にみた学びたい内容

64 人中の 15 人、 $23.4 \%$ 「学びたい」項目でも挙げている。この $84.2 \%$ を学習率、 $23.4 \%$ を再学習希望率と呼ぶことにする。再学習 希望率を縦軸に、学習率を横軸にしたものが図 6 である。なお学習 率が低い場合、再学習希望率はその内容によるだけでなく回答者の 意識を反映する可能性も高く、信頼性は低くなると思われる。

学習率が高く再学習希望率が低い項目は右下に集まっており、「機 能・役割」「気候・風土」など「住居の原論」型がそれにあたる。一 方、学習率は低いが再学習希望率が高い項目には「インテリア計画」 「清掃手入れ」「設計」「住宅問題」「自然災害」「環境共生」などがみ られる。具体的なテーマや現代的課題に関連した内容についてはさ らに学びたいとの意欲が示され、原論的内容については小・中・高 を通して学んできて理解しているためか再学習希望率は低い。

また、学習率も再学習希望率も相対的に高い項目には「住居の計 画」がある。間取りや平面計画が関連する授業は、教員と学習者双 方の立場から実施しやすく理解しや寸い典型的な学習内容ではない かと思われる。逆に、「住宅政策」「住まいの歴史」は学んだ人も少 ない上に再学習希望率も低いことから、学習者の実態に即して興味 を持たせる授業になりにくい要素があることが予想される。

学習経験や学習希望、再学習希望のいずれにおいても回答率が低 い項目に「住まいの歴史」（以下、歴史）と「住宅政策」（以下、政 策)がある。これらを学習志向性という側面から整理すると、「歴史」 は「住居の原論・住文化」に属し、学んだ内容での上位項目の「住 まいの機能・役割」や「気候・風土と住まい」との関連が深いと考 えられる。同様に、「政策」は「住居と社会」の学習志向性に属し、 学びたい内容での上位項目の「住宅の選び方や買い方借り方」(以下、 住宅選択）などとの関連があると思われる（表 8)。 


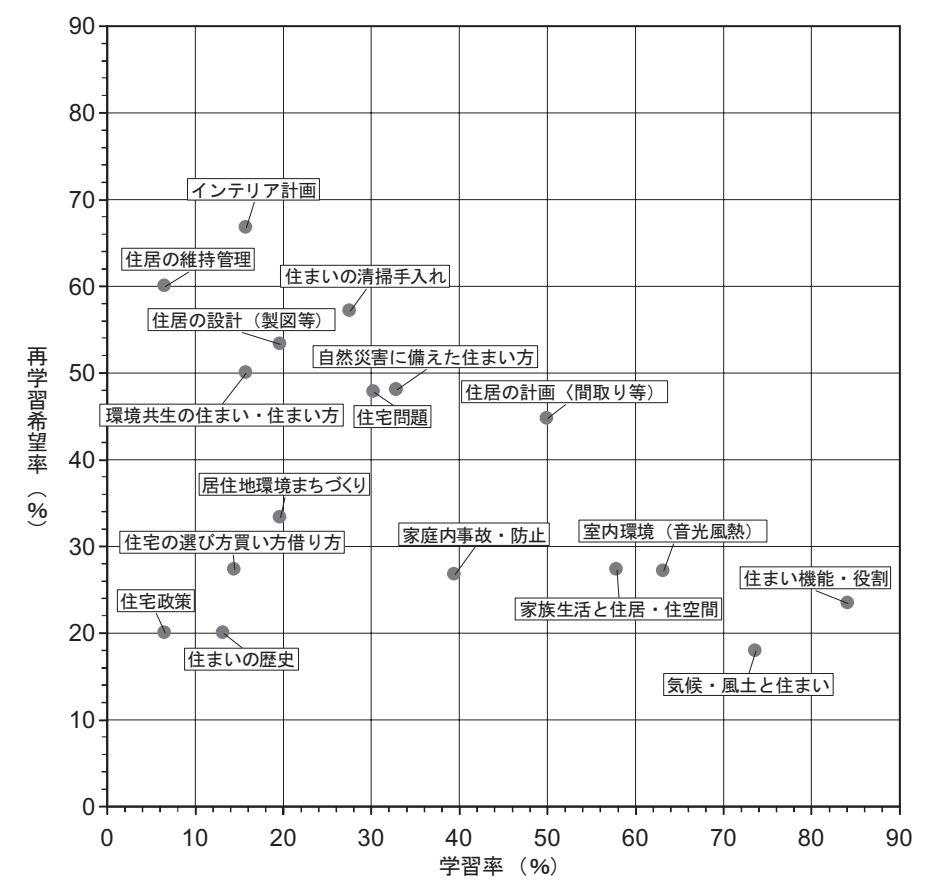

図 6 学習率と再学習希望率でみる住居領域の項目

このように学習希望だけでみると、学生にとって関心が低い内容 という側面だけで捉えられがちな学習項目も、学習志向性という切 り口でみると、学生にとっての関心項目の領域性や関連性によって 捉え直すことができ、学習内容をより構造的なものとして把握でき ると考えられる。学習志向性からみて関連性を持つ項目間にどのよ うな意味や関係があるのかについては、今後さらに詳細に分析する 必要がある。

\section{8. 結論}

本稿は食物系・家政教育系・住居系という比較的家庭科での住居 領域に関心があると想定される大学生を対象に、住居領域の学習内 容についての彼らの意識を中心に把握し、以下の知見を得た。

高等学校までに住居領域の学習を経験してきた者は全体の約半数 強で、半数弱は覚えていない者や学んだ意識のない者であり、学校 教育での住教育が充実しているとは言い難い現状がうかがえた。学 習経験者による学んできた内容の上位項目は「住まいの機能」や「気 候・風土と住まい」、室内環境」など、家庭科の学習指導要領に「小・ 中・高」や「中・高」と連続して記載されている内容で、下位項目 は「住宅政策」や「住まいの歴史」など、指導要領には記載されて いない内容や住まいの社会性が関連する内容であった。一方、学習 率の高低とは別に、学んできた内容の組み合わせが存在し、5 つの 成分が見いだせた。

学びたいと思う学習内容の上位には、「インテリア計画」など、具 体的で住宅・住空間に直接関連する内容という共通性がみられた。 下位項目は「住まいの歴史」や「住宅政策」など社会科学的な視点 が必要で、日常生活とは直接的な関連性が見出しにくい内容である とみられた。この学びたい内容についても回答組み合わせを基に、 5 つの学習志向性が見出せた。また、学びたい内容は基本属性や現在 の専門性、あるいは学習経験とも関連する傾向がみられた。

一連の分析から、学習経験や学習希望において回答率が低い学習
内容は住まいの社会的側面に触れるものと思われた。ただ、それら に関心のある学生の回答組み合わせをみると、学習希望の高い他の 項目などとも関連させて関心がもたれているらしいことが一部でう かがえた。

今回は、学習内容の構造化の試みを、まずは学生の学習志向性と いう側面を中心に行ったが、学習内容を構成する個々の項目間の関 係性には、例えば社会性といったような、ある一定の特性といえる 軸が見いだせると想定できた。

今後、より詳細な分析の中で学習項目の体系化を試みてゆくが、 例えば、指導困難性（あるいは学習困難性）があると言われてきた 学習内容に共通する性質がわかれば、それを踏まえた上での適切な 方策を打ち出せ、解決が導かれることになるかもしれない。また、 学習内容間の関係性がわかれば、学習内容の適切な組み合わせが見 いだせるであろう。それをもとにすれば、学習者の特性や地域性を 活かした授業内容を構築できるのではないかと考える。

当然ながら、教育すべき内容と学習者が学びたいとする内容とが 一致するとは限らない。学習者の関心の薄い内容をいかに教育する かが重要な課題となる場合も多い。今後の課題としては、学習内容 の構造化をす寸めていくにあたり、他の専門性を持つ大学生あるい は小・中・高校生など教育段階別にみた学習志向性にも着目し、比 較分析をすることが肝要であるし、教員側から捉えた住居領域内容 についての意識を把握することや、住居領域と家庭科教育、さらに は学校教育の理念からみて必要な住居領域内容を導き出すことも課 題である。

今回は学習者の立場から学習内容がどのように認識されているか を把握した。本来の構造化はそのような意識にも対応しながら、教 育における実効性のある体系を獲得するためのものである。本研究 が課題とする住居領域学習内容の構造は、学術的側面にとどまらず 意識的側面からも構築しようとしているが、得られた知見からは両 者に一定の関係性があると認められる。例えば社会的分野や技術的 分野、デザイン的分野などが学術的には分類できるが、学習者の意 識にも対応する分類があるとみられる。そのことは学術分野自体の 形成プロセスから当然ともいえるが、教育方法を検討する上でそれ を確認できたことは重要であると考える。今後の課題としては、そ れら分類ごとに住教育に関わる課題を整理し、検討していくことに なる。

\section{参考文献}

1）速水多佳子, 関川千尋：学校教育における住居領域の教育システムの有 効性について, 日本家政学会誌, Vol.51, No.4, pp. 317-330, 2000

2) 日本住宅総合センター：住教育の推進方策と住教育ガイドラインの策定 に関する検討調査, 日本住宅総合センター, 2008

3）湯川聰子, 谷崎通子, 原佐緒里：教師の立場からみた住居領域内容につ いて一高校家庭科における住教育内容の提案（第一報）, 日本家政学会誌,

Vol.45, No.5, pp.431-435, 1994

4）湯川聰子, 原佐緒里 : 生徒の学習要求と教師側意見の比較一高校家庭科に おける住教育内容の提案（第 2 報），日本家政学会誌，Vol.47，No.10， pp.1015-1021, 1996

5）立松麻衣子, 湯川聰子：住居学習に関する教師と生徒の関心の所在 中 学校技術・家庭科における住教育内容の検討 (第 1 報)，日本家政学会誌， Vol.54, No.5, pp.387-394, 2003

（2011年 6 月 1 日原稿受理， 2012年 1 月11日採用決定） 